\title{
The Length of Ministerial Tenure in the United Kingdom, 1945-97
}

\author{
SAMUEL BERLINSKI, TORUN DEWAN AND KEITH DOWDING*
}

\begin{abstract}
We analyse the determinants of ministerial hazard rates in Britain from 1945 to 1997 . We focus on three sets of attributes (i) personal characteristics of the minister; (ii) political characteristics of the minister; and (iii) characteristics pertaining to the government in which the minister serves. We find that educational background increases ministers' capacity to survive, that female ministers have lower hazard rates and older ministers have higher hazard rates. Experienced ministers have higher hazard rates than newly appointed ministers. Ministerial rank increases a minister's capacity to survive, with full cabinet members having the lowest hazard rates in our sample. We use different strategies to control for the characteristics of the government the minister serves in. Our results are robust to any of these controls.
\end{abstract}

In the British political system, where policy making is the primary function of departments, rising to ministerial office represents the height of ambition for most backbenchers. Yet we know little about what determines which ministers are successful. James Alt begins his essay on continuity and turnover in the British cabinet with the words: 'It is perhaps more difficult to place this study in the context of the academic literature than to show that it covers a topic of some importance. ${ }^{1}$ Over a quarter of a century later, with the exception of the study by Alt, the literature on ministers in the British cabinet still lacks systematic analysis. Blondel's comment a decade later remains pertinent: the 'study of ministers and ministerial careers is in its infancy'. ${ }^{2}$

Of course there is a large literature on the British cabinet. But the historical-cumdescriptive style has largely been concerned with relationships between the prime minister and cabinet colleagues, charting the ever advancing dominance of the premier. ${ }^{3}$ Useful histories have described the differing styles of prime ministers. ${ }^{4}$ Writings in constitutional lore have examined the changing role of collective and individual ministerial responsibility, ${ }^{5}$ and some systematic analysis of ministerial resignations has begun. ${ }^{6}$ On ministers

* Berlinski, Department of Economics, University College London and Institute for Fiscal Studies; Dewan and Dowding, Department of Government, London School of Economics and Political Science.

1 James E. Alt, 'Continuity, Turnover and Experience in the British Cabinet, 1868-1970', in Valentine Herman and James E. Alt, eds, Cabinet Studies: A Reader (London: Macmillan, 1975), pp. 33-54, at p. 33.

2 Jean Blondel, Government and Ministers in the Contemporary World (London: Sage, 1985), p. 8.

${ }^{3}$ For example, Peter Hennessy, Cabinet (Oxford: Basil Blackwell, 1986); Richard Heffernan, 'Prime Ministerial Predominance? Core Executive Politics in the UK', British Journal of Politics and International Relations, 5 (2003), 347-72.

4 For example, G. P. Thomas, Prime Minister and Cabinet Today (Manchester: Manchester University Press, 1998); Peter Hennessy, The Prime Minister: The Office and Its Holders Since 1945 (London: Penguin, 2001); Dick Leonard, A Century of Premiers: Salisbury to Blair (Houndmills, Hants.: Palgrave Macmillan, 2005).

5 For example, Sir R. Scott, 'Ministerial Accountability', Public Law (Autumn, 1996), 410-26; Diana Woodhouse, 'The Reconstruction of Constitutional Accountability', Public Law (Spring, 2002), 73-90.

${ }^{6}$ Keith Dowding, The Civil Service (London: Routledge, 1995), chap. 8; Keith Dowding and Won-Taek Kang, 'Ministerial Resignations 1945-97', Public Administration, 76 (1998), 411-29; Torun Dewan and Keith Dowding, 'The Corrective Effect of Ministerial Resignations on Government Popularity', American Journal of Political Science, 49 (2005), 46-56. 
themselves little has been written. There are a few biographical studies of the careers of ministers, and some, including former ministers, ${ }^{7}$ have considered what the ministerial role entails. Headey's idiosyncratic study of the behaviour and role of ministers in the 1960s is still the most comprehensive study of ministers in Britain. ${ }^{8}$ However, there are few studies of ministerial behaviour that are not directly related to the relationship between the prime minister and her cabinet colleagues. ${ }^{9}$ To some extent this reflects the central importance of the prime minister, but that central role does not entail that ministerial careers are not an interesting study in their own right.

We know historically that average length in which ministers serve in the full cabinet is less in Britain than many other countries, ${ }^{10}$ leading to the oft-bemoaned complaint that the British cabinet lacks experience. Alt has shown that continuity of full cabinet office declined from 1868 to 1915 when the present patterns were largely established. Experience measured by years as a full member of the cabinet has also declined since the nineteenth century, though more slowly, with increasing turnover in both personnel and officeholding. ${ }^{11}$ But not much more is known. In this article we try to take systematic analysis a little bit further. We focus here on ministerial tenure in the British government in the post-war period (1945-97), providing a first look at a map of the terrain. Abstracting from the economic and political problems faced by individual cabinets, the personal effects of individual premiers and all the specific features that lead to the termination of office, such as scandals and internal strife, we examine the effects of ministerial characteristics on length of ministerial tenure.

Ministers leave government for a variety of reasons. Dramatic resignations over sexual or financial scandals or over policy disagreements are ones which make the headlines, but most ministers end their careers either in a reshuffle or following the fall of a government. The fall of a government signals a failure in government policy for which each minister, by the terms of collective cabinet responsibility, must share some of the blame. Where a minister is shuffled out he is seen to have served his time, perhaps honourably and well, but nevertheless to be replaced by somebody the prime minister believes will do a better job. Thus, length of tenure must be some indicator of performance. Of course, ministers get chosen for all sorts of reasons. Because they represent powerful factions in the party, are crucial political or personal allies of the prime minister or simply seen as potentially adept ministers. But whatever the reason they are chosen, they will only progress and remain as ministers if they perform well. Of course 'perform well' can mean many things. At one level it means avoid the kind of scandals that cause ministers to resign. At another it can mean run their brief intelligently and well. Some ministers are better at getting on top of the detail of their work, others at facing parliament. But whatever their achievements and failings, length of tenure gives some indication of ministerial success and is thus an important variable to analyse.

Apart from the Alt study there has been no systematic analysis of ministerial tenure. The major drawback in analysing ministerial tenure, certainly in Britain, has been the lack

7 Notably Gerald Kaufman, How to be a Minister (London: Faber and Faber, 1997).

${ }^{8}$ Bruce Headey, British Cabinet Ministers (London: Allen and Unwin, 1974).

${ }^{9}$ Following the standard use in formal principal-agent modelling we use the female pronoun for prime ministers (principal) and male pronoun for ministers (agents) - unless we refer to actual people, where we use the appropriate pronoun.

10 Valentine Herman, 'Comparative Perspectives on Ministerial Stability in Britain', in Herman and Alt, eds, Cabinet Studies, pp. 55-76.

11 Alt, 'Continuity, Turnover and Experience'. 
of data. This article is based on a dataset which records the employment spells for all ministers in Britain from 1945 to $1997 .{ }^{12}$ The data includes the rank of the minister (cabinet ministers, minister of state, junior minister or whip), whether the minister is an elected MP or a non-elected member of the House of Lords, and the government and prime minister under which they served. As well as these features, the data also records a number of personal characteristics of each minister including their age, gender, level of education and their previous experience as a minister.

To analyse length of tenure we look at the duration of each ministerial spell. An intuitive approach is to relate durability to the performance of a minister in the job. In this article we do not include performance variables, focusing instead on characteristics of a minister which may or may not be related to performance. Our primary concern in this article is to highlight those characteristics of ministers that might increase the length of time a minister survives which, borrowing from the government duration literature, we refer to as ministerial durability. ${ }^{13}$ In much the same way that the durability of cabinets is subject to random shocks, ministers too can be seen as subject to random events that may lead to the termination of a ministerial spell. However, there may also be characteristics of individual ministers and of governments that enhance a minister's survival capacity. Our aim in this article is to provide the first description of the characteristics that lead to ministerial durability.

We focus on three sets of attributes: (i) personal characteristics of the minister; (ii) political characteristics of the minister, and (iii) characteristics pertaining to the government in which the minister serves. We find that educational background increases ministers' capacity to survive, that female ministers have lower hazard rates and older ministers have higher ones. Experienced ministers have higher hazard rates than newly appointed ones. Ministerial rank increases a ministers' capacity to survive, with full cabinet members having the lowest hazard rates in our sample. We use different strategies to control for the characteristics of the government in which the ministers serve. Our results are robust to any of these controls.

The rest of the article is organized as follows. We describe our research question and design in more detail below. In the following section we present the data and provide a descriptive analysis of ministerial composition in different governments and in different positions. Then, we provide a multivariate analysis of the effect of individual characteristics on hazard rates. We finish the article with some concluding remarks.

\section{RESEARCH QUESTION AND DESIGN}

The precise question addressed in our statistical analysis is: 'What is the likelihood that a ministerial spell will end at any point in time since the minister's appointment, given how long she has lasted thus far?' We treat a ministerial spell as the length of time which a minister serves in a given administration. Our research design draws upon previous analysis of government duration: we model the stochastic element of ministerial tenure

\footnotetext{
12 Putting constitutional niceties aside we refer to everyone in our dataset as a 'minister'. In fact, it includes full cabinet ministers, ministers of cabinet rank, junior ministers and government whips. All positions are within the patronage of the prime minister. It does not include parliamentary private secretaries, as these, whilst confirmed by the prime minister are usually chosen by the minister.

${ }^{13}$ Gary King, James Alt, Nancy E. Burns and Michael Laver, 'A Unified Model of Cabinet Dissolution in Democracies', American Journal of Political Science, 41 (1990), 846-71.
} 
whilst taking into account effects that are fixed at the time of the minister's entry into government.

There are a number of features which one would wish to take account of in such analysis. Our first and primary concern is to analyse the effect of the individual characteristics of a minister - such as educational background and ministerial experience - on the length of time he serves. Some features, such as education are fixed when a minister enters a government and are unrelated to anything done during office. We ask how these fixed traits affect the subsequent length of time served as a minister. In addition we estimate the effects of characteristics that ministers attain during their political career such as experience in government. With our data we are able to address the question: how does the experience of being a cabinet minister in a previous administration affect the expected tenure of a minister in a subsequent administration? We are also able to address the effects of ministerial characteristics which may change during a spell in government. Specifically, we assess the effect of ministerial rank upon length of tenure.

These ministerial characteristics might have both direct and indirect effects upon tenure. The options ministers have outside of politics may be affected by their educational background, which might directly affect length of tenure. If a minister is under stress or under pressure to resign, the value of his 'outside options' might influence the decision of whether to stay or to quit. Higher education and the broader network of acquaintances made at university might lead to greater opportunities outside of government. A minister who is under pressure, but who has career opportunities outside of politics, might not wish to stick around. However, educational background might help a minister to survive. Informal networks based upon acquaintances made at school and university might provide some protection for a minister during times of trouble.

Ministerial performance is likely to be related to personal abilities and these might be indirectly related to their characteristics. One might think of an able minister as someone who performs well in the various tasks involved in the ministerial role. What it takes to be an able minister in this sense is open to much debate, ${ }^{14}$ though it is likely that ability to perform well in whatever sphere is related to fixed ministerial characteristics. For example, better educated ministers might be better able to handle their civil servants or even the dispatch box. There is no better tuition for facing the House of Commons than debating at the Oxford Union. Edward Heath was not awestruck when first elected: 'when I first went to the House of Commons, in 1950, I felt I was coming home. ${ }^{15}$ Educational variables (Oxbridge and public school) may thus increase durability. Experience may also relate to an ability to perform one's job, since more able ministers are more likely to accumulate experience. Thus, in taking into account the direct and indirect effect of experience we make no direct causal claim about its effect.

To illustrate our research design more clearly, suppose that, when observing the failure of ministers, the impact of different traits could be be modelled linearly. Moreover, assume for the time being that we observe the failure of all ministers (i.e., there is no censoring). We might then write the following model:

$$
T_{i g f}=\alpha+X_{i g} \beta^{\prime}+Z_{i g f} \gamma^{\prime}+B_{g} \delta^{\prime}+P_{g f} \lambda^{\prime}+\varepsilon_{i g f},
$$

${ }^{14}$ See Headey, British Cabinet Ministers, or Bruce Headey, 'The Role Skills of Cabinet Minsters: A Cross-National Review', Political Studies, 22 (1974), 66-85, for discussion of what makes able ministers.

15 David Walter, The Oxford Union: Playground of Power (London: MacDonald, 1984), p. 11, cited by Jeremy Paxman, The Political Animal (Harmondsworth, Midx.: Penguin, 2002), p. 53. 
where $T_{i g f}$ is the completed spell of minister $i$, in government $g$, at the time of failure $f$; $X_{i g}$ is the set of fixed individual characteristics (such as educational background) that a minister brings into government at the start of his job; and $Z_{i g f}$ is a vector which contains measures of ministerial performance and includes his performance at different points in time in his job and his performance at the time of failure. $B_{g}$ is a vector of characteristics of the government that the minister serves in; for example, the party in power or its majority. ${ }^{16} P_{g f}$ is a vector of factors that capture the overall performance of the government up to time $f$.

Of course, $Z$ is implicitly a function of $X$ : a minister's performance is related to the characteristics he brings to government. Similarly $P_{g f}$ is also related to $Z$ and thus to $X$ : the overall performance of the government is affected by the performance of individual ministers and, indirectly, by the characteristics of those ministers. Thus, the characteristics of ministers are likely to have an effect on tenure through various channels: directly, as captured by the vector $\beta^{\prime}$; and indirectly through the effects on $Z$ and $P_{g f}$.

If MPs were randomly allocated into government then a simple comparison of means of $T_{i g f}$ between ministers with different characteristics would measure the causal effect of these characteristics on tenure. This parameter would capture both the direct and indirect effects of ministerial characteristics and it is this parameter that we attempt to identify in this article. Obviously, MPs are not randomly selected into governments. When we look at the effect of $X_{i}$ on $T_{i g f}$ we may well be confounding characteristics of the government with that of individuals. For example, the educational backgrounds of Conservative and Labour MPs differ systematically. When we estimate the effects of education we may confound different effects: the effect of educational background and the effect of belonging to a government of a particular party in which ministers share similar educational backgrounds. We tackle this problem by using models which add government characteristics to the set of variables, and in some of our models we also use government fixed effects (see Table 4 below). One of the key findings of this article is that the effects of ministerial characteristics upon tenure are surprisingly robust to the inclusion of these control variables. ${ }^{17}$

For illustrative purposes, we have described a model in which tenure is linearly related to ministerial characteristics. The type of question we outline is, however, not well answered using ordinary least-squares regression. This is in part due to the fact that the assumption of normally distributed errors is unlikely to hold when length of time until an event is the dependent variable. Another issue is that of censoring of the data which we discuss more fully below. Duration models, which are designed to address these issues, are widely used in political science and these have a number of desirable features as discussed by Box-Steffensmeier and Jones. ${ }^{18}$ The duration model focuses on the hazard rate, that is the instantaneous probability that a spell is terminated. We use the Cox proportional-hazards model allowing us to model the stochastic elements without

\footnotetext{
${ }^{16}$ In fact, we only code for majority at the start of the government's term of office. Its majority at any point thereafter is highly correlated with its majority at the start of its term. To code each time an MP dies, switches parties or a by-election is held would require a new entry for each minister on each occasion.

17 It could be further claimed that our analysis is biased because we include ministers who entered after the government started. However, our results are robust to looking only at ministers who entered at the start of government.

18 Janet M. Box-Steffensmeier and Brad Jones, 'Time Is of the Essence: Event History Models in Political Science', American Journal of Political Science, 41 (1997), 1414-61.
} 
making restrictive assumptions. We express the hazard rate for minister $i$ in government $g$ as

$$
\lambda_{i g t}=\lambda_{0}(t) \times \exp \left(X_{i g} \theta^{\prime}+B_{g} \pi^{\prime}\right),
$$

where $\lambda_{0}(t)$ is the minister's baseline hazard at $t$, that is the hazard rate when all measures of characteristics which may affect a minister's durability are recorded as zero; $X$ is a vector of individual characteristics which may affect a minister's durability; and $B$ characteristics of the government in which he serves. The key contribution of this article is in providing a vector of estimates $\theta$ of the effect of various ministerial characteristics.

Our analysis focuses upon the effects of ministerial attributes and political factors upon the length of time a minister serves in government. We analyse the length of time that elapses from when a minister enters government until he leaves or the government terminates. A minister leaves the government following an individual resignation or following a reshuffle. We treat the end of a government term as occurring either when there is an election, or when there is a change of prime minister. We treat the starting day for each minister as occurring two weeks from the day the government is formed thus allowing for a period during which the prime minister might shuffle the cabinet. ${ }^{19}$ Similarly, we censor everybody two weeks before the end of government just to avoid problems generated by coding errors at the end of governments. ${ }^{20}$

\section{DATA AND DESCRIPTIVE ANALYSIS}

We have gathered data on all ministers from 1945 to 1997. Each minister is coded according to rank and the government and prime minister under whom he serves. ${ }^{21}$ Each minister is also coded for date of birth, education, gender and whether not the minister is an unelected peer. Table 1 provides the definitions of each of the variables used in the analysis and provides basic descriptive statistics for the whole sample.

Over the period of our analysis there have been 924 people who have been ministers (545 Conservatives and 379 Labour, with eight people holding positions under both party labels). Of these only forty-seven have been women. Over that time there have been 226 full cabinet ministers, 496 ministers of state, 525 junior ministers and 271 whips, making 1,512 observations of ministers in total. ${ }^{22}$ Only nine women have been full cabinet ministers (five Conservative and four Labour). Of the women only Margaret Thatcher as prime minister has made it to one of the top four cabinet positions. ${ }^{23}$ The number of female

19 These days the post-election shuffle rarely takes more than a couple of days, but in the past shuffling the cabinet was a more leisurely affair.

${ }^{20}$ We chose this rule since David Butler and Gareth Butler in Twentieth Century British Political Facts 1900-2000 (Houndmills: Macmillan, 2000), from which we get most of our data, report different end dates for ministers following a new government forming with its usual reshuffle. Some are given as ending just before the new government forms, some with the reshuffle. Some whips resign between the calling of an election and the election itself. However, all these are on a par. We believe there are no cases of genuine resignation other than as part of the general clear out and reshuffle during the last two weeks of government. Might this censoring rule effect the estimates of the hazard rate? In this respect the Cox proportional model assumes that the duration function may take any form, so that the beginning or end of government is unlikely to bias our analysis as long as the proportionality assumption is correct.

${ }^{21}$ If they appear in Butler and Butler, British Political Facts, then virtually all ministers as we define them are included in our sample. Reasons for exclusion include lack of information on age or inconsistencies in Butler and Butler that we were not able to rectify from other sources.

${ }^{22}$ The numbers in the latter four categories of observations of ministers is larger than the number of people since many people have had positions at various levels.

${ }^{23}$ Prime minister, chancellor of the exchequer, home secretary and foreign secretary. 
TABLE 1 Definition of Variable and Descriptive Statistics

\begin{tabular}{|c|c|c|}
\hline Variable & Definition & $\begin{array}{l}\text { Mean } \\
\text { (std. dev.) }\end{array}$ \\
\hline Tenure & $\begin{array}{l}\text { Ministerial tenure in months by government. Failure is } \\
\text { defined as leaving government at least two weeks before the } \\
\text { end of government. There are no left censored variables. } \\
\text { Right censoring occurs when someone is still in post two } \\
\text { weeks before the end of a government term. Ministers who } \\
\text { fail during the first two weeks of government are dropped. }\end{array}$ & $\begin{array}{c}26.90 \\
(16.46)\end{array}$ \\
\hline Public school & $\begin{array}{l}\text { Dummy variable equal to one if attended public school and } \\
\text { zero otherwise. }\end{array}$ & 0.62 \\
\hline Oxbridge & $\begin{array}{l}\text { Dummy variable equal to one if attended university at Oxford } \\
\text { or Cambridge and zero otherwise. }\end{array}$ & 0.50 \\
\hline Age & Age in years at the start of ministerial spell. & $\begin{array}{l}49.17 \\
(8.78)\end{array}$ \\
\hline Female & Dummy variable equal to one if female and zero otherwise. & 0.05 \\
\hline $\begin{array}{l}\text { Some } \\
\quad \text { experience }\end{array}$ & $\begin{array}{l}\text { Dummy variable equal to one if a minister has served under } \\
\text { previous governments and zero otherwise. }\end{array}$ & 0.61 \\
\hline $\begin{array}{l}\text { Experience } \\
\text { in years }\end{array}$ & $\begin{array}{l}\text { Years of experience in previous governments at the start of } \\
\text { ministerial spell. }\end{array}$ & $\begin{array}{c}2.70 \\
(3.42)\end{array}$ \\
\hline $\begin{array}{l}\text { Unelected } \\
\text { peer }\end{array}$ & $\begin{array}{l}\text { Dummy variable equal to one if unelected peer and zero } \\
\text { otherwise. }\end{array}$ & 0.21 \\
\hline $\begin{array}{l}\text { Cabinet } \\
\text { ministers }\end{array}$ & $\begin{array}{l}\text { Dummy variable equal to one if cabinet minister and zero } \\
\text { otherwise. }\end{array}$ & 0.16 \\
\hline $\begin{array}{l}\text { Ministers } \\
\text { of cabinet } \\
\text { rank }\end{array}$ & $\begin{array}{l}\text { Dummy variable equal to one if minister of cabinet rank and } \\
\text { zero otherwise. }\end{array}$ & 0.30 \\
\hline $\begin{array}{l}\text { Junior } \\
\quad \text { ministers }\end{array}$ & $\begin{array}{l}\text { Dummy variable equal to one if junior minister and zero } \\
\text { otherwise. }\end{array}$ & 0.35 \\
\hline $\begin{array}{l}\text { Whips and } \\
\text { members } \\
\text { of HM } \\
\text { Household }\end{array}$ & $\begin{array}{l}\text { Dummy variable equal to one if Whip and Member of HM } \\
\text { Household and zero otherwise. }\end{array}$ & 0.19 \\
\hline Majority & $\begin{array}{l}\text { Majority is defined as the share of the house commanded by } \\
\text { the governing party in percentages. }\end{array}$ & $\begin{array}{l}54.35 \\
(4.01)\end{array}$ \\
\hline Labour & $\begin{array}{l}\text { Dummy variable equal to one if prime minister belongs to the } \\
\text { Labour party and zero otherwise. }\end{array}$ & 0.37 \\
\hline Term & $\begin{array}{l}\text { Term currently being served by the prime minister. When we } \\
\text { condition on this variable in the regression analysis we use } \\
\text { two dummies. }\end{array}$ & \\
\hline $\begin{array}{l}\text { Prime } \\
\text { minister }\end{array}$ & $\begin{array}{l}\text { Eleven prime minister identifiers. When we condition on this } \\
\text { variable in the regression analysis we use ten dummies. }\end{array}$ & \\
\hline
\end{tabular}

Notes: The source of information is Butler and Butler, Twentieth Century British Political Facts. There are 2,235 spells in total. 
TABLE 2 Average Characteristics of Ministers by Government

\begin{tabular}{|c|c|c|c|c|c|c|c|c|c|c|}
\hline \multirow[b]{2}{*}{ Variables } & \multicolumn{2}{|c|}{$\begin{array}{c}\text { Attlee } \\
1945-50\end{array}$} & \multicolumn{2}{|c|}{$\begin{array}{c}\text { Attlee } \\
1950-51\end{array}$} & \multicolumn{2}{|c|}{$\begin{array}{l}\text { Churchill } \\
1951-55\end{array}$} & \multicolumn{2}{|c|}{$\begin{array}{l}\text { Eden } \\
1955\end{array}$} & \multicolumn{2}{|c|}{$\begin{array}{c}\text { Eden } \\
1955-57\end{array}$} \\
\hline & Mean & Std.d. & Mean & Std.d. & Mean & Std.d. & Mean & Std.d. & Mean & Std.d. \\
\hline Observed tenure & 38.53 & 17.59 & 17.72 & 5.36 & 32.33 & 13.15 & 1.55 & 0.09 & 16.28 & 5.59 \\
\hline Public school & 0.32 & 0.47 & 0.35 & 0.48 & 0.91 & 0.29 & 0.93 & 0.26 & 0.91 & 0.29 \\
\hline Oxbridge & 0.25 & 0.43 & 0.30 & 0.46 & 0.64 & 0.48 & 0.66 & 0.48 & 0.68 & 0.47 \\
\hline Age & 51.21 & 10.82 & 51.92 & 10.93 & 48.92 & 9.41 & 49.89 & 8.46 & 48.74 & 8.30 \\
\hline Some experience & 0.23 & 0.42 & 0.77 & 0.42 & 0.25 & 0.44 & 0.95 & 0.22 & 0.84 & 0.37 \\
\hline Experience in years & 1.03 & 2.11 & 3.72 & 3.23 & 1.42 & 2.97 & 3.96 & 3.48 & 3.23 & 3.30 \\
\hline Female & 0.03 & 0.16 & 0.02 & 0.15 & 0.02 & 0.14 & 0.01 & 0.11 & 0.02 & 0.14 \\
\hline Unelected peer & 0.16 & 0.37 & 0.21 & 0.41 & 0.23 & 0.42 & 0.27 & 0.45 & 0.22 & 0.42 \\
\hline Labour & \multicolumn{2}{|c|}{ Yes } & \multicolumn{2}{|c|}{ Yes } & \multicolumn{2}{|c|}{ No } & \multicolumn{2}{|c|}{ No } & \multicolumn{2}{|c|}{ No } \\
\hline \multirow[t]{2}{*}{ Observations } & \multicolumn{2}{|c|}{117} & \multicolumn{2}{|c|}{92} & \multicolumn{2}{|c|}{106} & \multicolumn{2}{|c|}{82} & \multicolumn{2}{|c|}{99} \\
\hline & \multicolumn{2}{|c|}{$\begin{array}{c}\text { Macmillan } \\
1957-59\end{array}$} & \multicolumn{2}{|c|}{$\begin{array}{c}\text { Macmillan } \\
1959-63\end{array}$} & $\begin{array}{r}\text { Dou } \\
\text { Ho } \\
196\end{array}$ & $\begin{array}{l}\text { glas- } \\
\text { me } \\
3-64\end{array}$ & $\begin{array}{r}\mathrm{Wi} \\
196\end{array}$ & son & $\begin{array}{r}\text { Wi } \\
196\end{array}$ & $\begin{array}{l}\text { son } \\
-70\end{array}$ \\
\hline Variables & Mean & Std.d. & Mean & Std.d. & Mean & Std.d. & Mean & Std.d. & Mean & Std.d. \\
\hline Observed tenure & 27.08 & 9.55 & 31.51 & 14.93 & 11.56 & 2.01 & 16.42 & 3.38 & 36.77 & 16.74 \\
\hline Public school & 0.90 & 0.30 & 0.84 & 0.37 & 0.84 & 0.37 & 0.33 & 0.47 & 0.31 & 0.46 \\
\hline Oxbridge & 0.68 & 0.47 & 0.65 & 0.48 & 0.66 & 0.48 & 0.30 & 0.46 & 0.31 & 0.46 \\
\hline Age & 48.36 & 7.46 & 47.39 & 7.17 & 48.36 & 7.33 & 52.90 & 8.70 & 50.38 & 9.66 \\
\hline Some experience & 0.73 & 0.44 & 0.59 & 0.49 & 0.89 & 0.31 & 0.17 & 0.38 & 0.67 & 0.47 \\
\hline Experience in years & 3.06 & 3.45 & 2.90 & 3.44 & 4.67 & 4.56 & 0.70 & 1.73 & 1.29 & 1.55 \\
\hline Female & 0.02 & 0.14 & 0.03 & 0.17 & 0.02 & 0.14 & 0.07 & 0.25 & 0.07 & 0.26 \\
\hline Unelected peer & 0.26 & 0.44 & 0.23 & 0.43 & 0.25 & 0.44 & 0.17 & 0.38 & 0.15 & 0.35 \\
\hline Labour & $\mathrm{N}$ & $\mathrm{o}$ & & $\mathrm{o}$ & & $\mathrm{o}$ & & & & es \\
\hline Observations & 9 & & & 32 & & 5 & 1 & & & 1 \\
\hline & $\mathrm{He}$ & ath & $\mathrm{Wi}$ & son & $\mathrm{Wi}$ & son & Calls & ghan & Tha & cher \\
\hline & 197( & -74 & & 74 & 197 & $1-76$ & 197 & -79 & 197 & -83 \\
\hline Variables & Mean & Std.d. & Mean & Std.d. & Mean & Std.d. & Mean & Std.d. & Mean & Std.d. \\
\hline Observed tenure & 32.28 & 15.46 & 6.86 & 0.91 & 16.24 & 4.21 & 32.39 & 10.68 & 38.54 & 14.71 \\
\hline Public school & 0.85 & 0.35 & 0.25 & 0.44 & 0.25 & 0.44 & 0.23 & 0.43 & 0.79 & 0.41 \\
\hline Oxbridge & 0.65 & 0.48 & 0.33 & 0.47 & 0.34 & 0.47 & 0.34 & 0.48 & 0.58 & 0.50 \\
\hline Age & 47.07 & 7.51 & 50.59 & 9.06 & 49.44 & 9.46 & 49.66 & 9.56 & 48.31 & 7.64 \\
\hline Some experience & 0.33 & 0.47 & 0.50 & 0.50 & 0.83 & 0.38 & 0.83 & 0.38 & 0.38 & 0.49 \\
\hline Experience in years & 1.49 & 3.01 & 2.17 & 2.55 & 2.36 & 2.58 & 2.93 & 2.65 & 1.33 & 2.46 \\
\hline Female & 0.02 & 0.15 & 0.06 & 0.24 & 0.08 & 0.27 & 0.07 & 0.26 & 0.03 & 0.17 \\
\hline Unelected peer & 0.24 & 0.43 & 0.16 & 0.37 & 0.18 & 0.38 & 0.18 & 0.38 & 0.19 & 0.40 \\
\hline Labour & $\mathrm{N}$ & & & es & & es & & & & \\
\hline Observations & 12 & & & 2 & & 19 & 1 & & & \\
\hline & That & cher & Tha & cher & M & jor & Mc & jor & & \\
\hline & 1983 & & 198 & 7-90 & 199 & )-92 & 199 & -97 & & \\
\hline Variables & Mean & $\overline{\text { Std.d. }}$ & Mean & Std.d. & Mean & $\overline{\text { Std.d. }}$ & Mean & Std.d. & & \\
\hline Observed tenure & 37.28 & 14.69 & 31.41 & 13.33 & 16.24 & 1.73 & 40.24 & 18.52 & & \\
\hline Public school & 0.76 & 0.43 & 0.75 & 0.43 & 0.76 & 0.43 & 0.69 & 0.46 & & \\
\hline Oxbridge & 0.60 & 0.49 & 0.55 & 0.50 & 0.53 & 0.50 & 0.48 & 0.50 & & \\
\hline Age & 47.88 & 8.20 & 47.55 & 8.12 & 48.52 & 8.08 & 48.62 & 8.30 & & \\
\hline Any experience & 0.66 & 0.47 & 0.68 & 0.47 & 0.94 & 0.25 & 0.62 & 0.49 & & \\
\hline Experience in years & 2.96 & 3.06 & 3.77 & 3.88 & 5.47 & 4.32 & 3.88 & 4.44 & & \\
\hline Female & 0.06 & 0.24 & 0.06 & 0.24 & 0.08 & 0.28 & 0.08 & 0.27 & & \\
\hline Unelected peer & 0.24 & 0.43 & 0.22 & 0.41 & 0.21 & 0.41 & 0.19 & 0.40 & & \\
\hline Labour & $\mathrm{N}$ & o & & O & & o & & & & \\
\hline Observations & 13 & 34 & & 42 & & 9 & 1 & & & \\
\hline
\end{tabular}

Note: See Table 1 for the definition of variables. 
ministers has ranged between 2 per cent and 8 per cent, the highest number being under the Major government. Of all these ministers 297 have been peers and 1215 elected MPs. ${ }^{24}$ The average age of those on the payroll has remained about the same at around 50, or just below, over the period.

In all, our analysis spans nineteen terms from the first Attlee administration until the end of John Major's second term. ${ }^{25}$ These include seven Labour and twelve Conservative governments. Table 2 provides some summary statistics of the attributes of ministers in our sample by the government in which they served. A good way of summarizing the information in Table 2 is to focus on the differences between Labour and Conservative governments. The mean observed tenure for Conservative ministers is twenty-eight months, whereas for Labour ministers the corresponding figure is twenty-five months. There is quite a large variation in education between Conservative and Labour administrations. On average 81 per cent of Conservative ministers have attended public school and 60 per cent of Conservative ministers have been to Oxbridge. This compares with an average of 29 per cent of Labour ministers with a public school education, with 31 per cent of Labour ministers having been to Oxbridge. ${ }^{26}$ Another interesting difference in the partisan composition of governments is that 23 per cent of Conservative ministers are unelected peers, which compares with only 17 per cent of Labour ministers. On average, 64 per cent of Conservative ministers have previous ministerial experience when entering government (the average experience of a Conservative minister being three years). This compares with 57 per cent of Labour ministers who have previous experience (the average experience of a Labour minister being two years).

Other features revealed in the data include the slightly falling level of public school education for both Labour and Conservative ministers over time, and a slight fall in average age. Average age of an incoming administration with new party colours is, unsurprisingly, lower than the average age of an administration that has been in power over several terms. But these differences are marginal to say the least. The average experience in years of ministers also varies from a low of 1.03 years for the incoming Atlee administration in 1945 to a high of 5.47 in Major's first administration. ${ }^{27}$ There is no trend discernible here, and experience varies largely with how long each party has been in or out of power.

Table 3 presents mean length of observed tenure and other average characteristics of our sample of ministers by the rank of the minister. ${ }^{28}$ The mean observed tenure is longer the further up the ministerial ladder you climb, but these differences are not very pronounced. On average, a cabinet minister serves two and a half months longer than a government whip. However, there are larger differences in the personal characteristics of ministers at different ranks. Cabinet ministers are older on average, some nine years older

24 Again these numbers do not add up to total people or total 'observations', since some people are counted as one observation of a 'ministerial career' having held office both as an elected MP and a peer.

25 From now on, prime ministers are excluded from the sample.

${ }^{26}$ It is also worth noting that the distinctions are maintained at full cabinet level. In terms of the full cabinet, whereas only half of Attlee's initial twenty ministers had attended university (five going to Oxbridge), twenty of Major's initial twenty-two went to university (seventeen to Oxbridge). It is also worth noting that it was not unusual for all the cabinet ministers to have been to public schools in some of the early Conservative administrations, indeed ten of Eden's eighteen cabinet ministers had been to Eton, and even six of Thatcher's first cabinet had attended that school (and two of Attlee's had also been to Eton). See Butler and Butler, British Political Facts, p. 71.

27 Major's second administration drops to 3.88 years which is still on the high side overall.

${ }^{28}$ We should note that whilst we have 2,235 spells, we do not have that number of separate people serving as ministers - since many people have served at several levels and during several administrations. 
TABLE 3 Average Tenure and Characteristcs of Ministers by Ministerial Rank

\begin{tabular}{|c|c|c|c|c|c|c|c|c|}
\hline \multirow[b]{3}{*}{ Variables } & \multicolumn{8}{|c|}{ Ministerial rank } \\
\hline & \multicolumn{2}{|c|}{$\begin{array}{l}\text { Cabinet } \\
\text { Ministers }\end{array}$} & \multicolumn{2}{|c|}{$\begin{array}{l}\text { Ministers of } \\
\text { Cabinet rank }\end{array}$} & \multicolumn{2}{|c|}{$\begin{array}{c}\text { Junior } \\
\text { Ministers }\end{array}$} & \multicolumn{2}{|c|}{$\begin{array}{l}\text { Whips and } \\
\text { Members of } \\
\text { HM Household }\end{array}$} \\
\hline & Mean & Std.d. & Mean & Std.d. & Mean & Std.d. & Mean & Std.d. \\
\hline Observed tenure & 28.05 & 16.76 & 27.23 & 16.63 & 26.83 & 15.99 & 25.54 & 16.75 \\
\hline Public school & 0.70 & 0.46 & 0.66 & 0.47 & 0.60 & 0.49 & 0.55 & 0.50 \\
\hline Oxbridge & 0.63 & 0.48 & 0.53 & 0.50 & 0.46 & 0.50 & 0.41 & 0.49 \\
\hline Age & 55.38 & 7.35 & 50.81 & 7.65 & 46.12 & 7.95 & 47.01 & 9.71 \\
\hline Some experience & 0.92 & 0.28 & 0.74 & 0.44 & 0.49 & 0.50 & 0.38 & 0.49 \\
\hline Experience in years & 6.48 & 4.03 & 3.48 & 3.46 & 1.33 & 1.88 & 0.79 & 1.57 \\
\hline Female & 0.03 & 0.17 & 0.04 & 0.19 & 0.06 & 0.24 & 0.05 & 0.22 \\
\hline Unelected peer & 0.18 & 0.39 & 0.25 & 0.43 & 0.11 & 0.32 & 0.34 & 0.47 \\
\hline Observations & \multicolumn{2}{|c|}{358} & \multicolumn{2}{|c|}{668} & \multicolumn{2}{|c|}{793} & \multicolumn{2}{|c|}{416} \\
\hline
\end{tabular}

Note: See Table 1 for the definition of variables.

than junior ministers, indicating that seniority brings its rewards in the British system of government. There are also differences to be found in the level of education at each ministerial rank. There is a positive correlation between rank and education: higher ranked ministers are more likely to have been educated in public school and to have gone to Oxbridge. In addition, it is noticeable that the average level of previous experience is six-and-a-half years for a cabinet minister, three-and-a-half years for a minister of cabinet rank, one year and four months for a junior minister and less than one year for a whip. Finally, our data show that unelected peers are over-represented at lower levels of government in comparison to higher posts. This is due to government needing representation for departments in the upper house but being greatly reluctant to having peers as full cabinet ministers.

In Figure 1, we present the Kaplan-Meier survivor function based upon all ministerial spells in the sample. Despite the common perception that ministerial tenure is precarious, we find that a typical ministerial spell will be rather long with 75 per cent of ministerial appointments lasting over thirty-five months. ${ }^{29}$

In Figure 2, we present Kaplan-Meier survivor functions for ministers with different individual attributes. The graphs show very similar survivor functions for ministers with a public school education and those without. However, ministers with an Oxbridge background appear to have higher survival rates, at least after twenty months in government have passed. Female ministers also appear to survive longer than their male counterparts, whereas, according to these graphs, ministers with previous experience have lower survival rates. ${ }^{30}$ Thus at first glance, these pictures appear to show evidence that

${ }^{29}$ This picture of ministerial stability prevails if each government is analysed separately, though we do not report these results here.

${ }^{30}$ Logrank tests confirm that the differences in the survivor functions of Oxbridge and experienced ministers are statistically significant. However, at conventional levels of statistical significance, we cannot reject the null of equality of survivor functions between female and male minsters. 


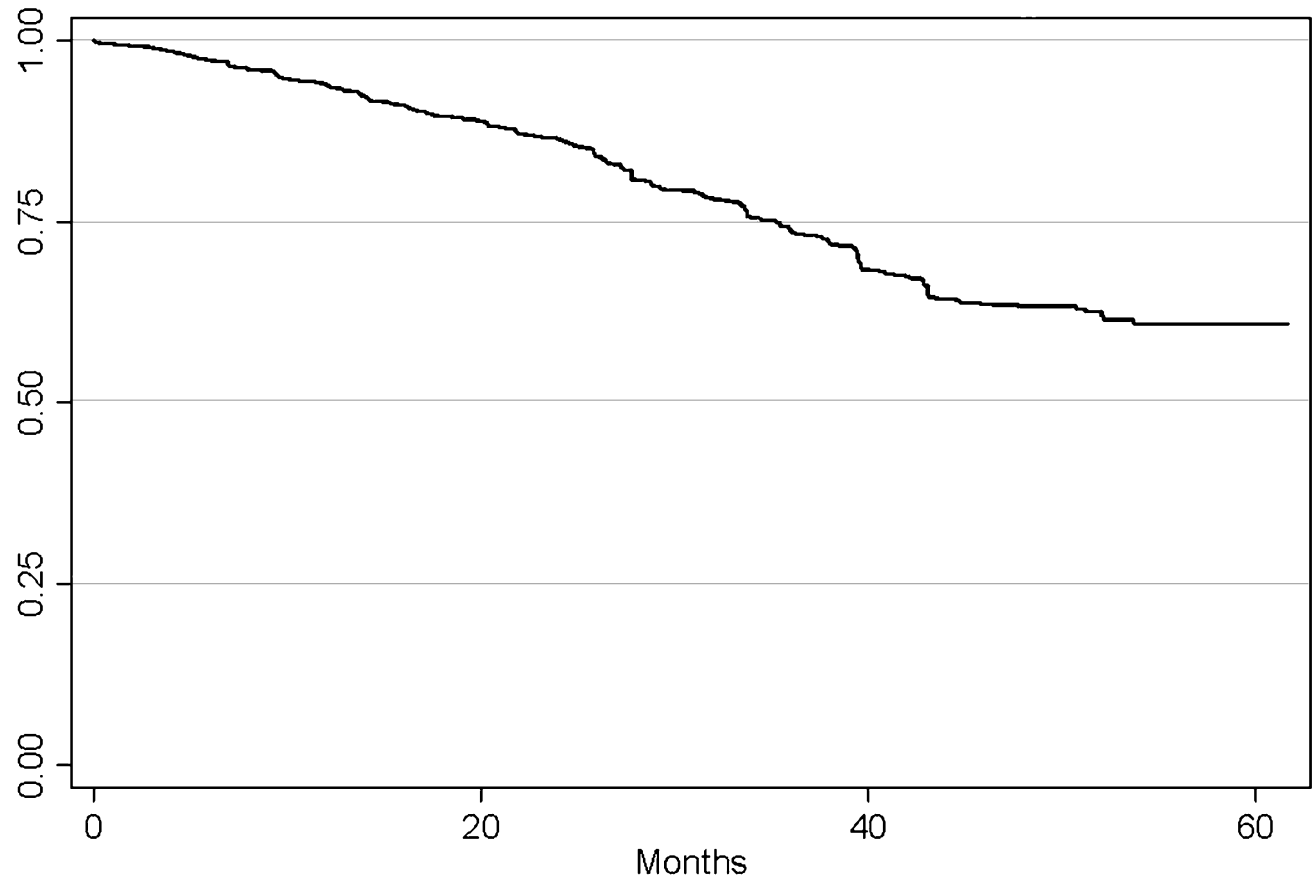

Fig. 1. Ministerial survivor function, 1945-97
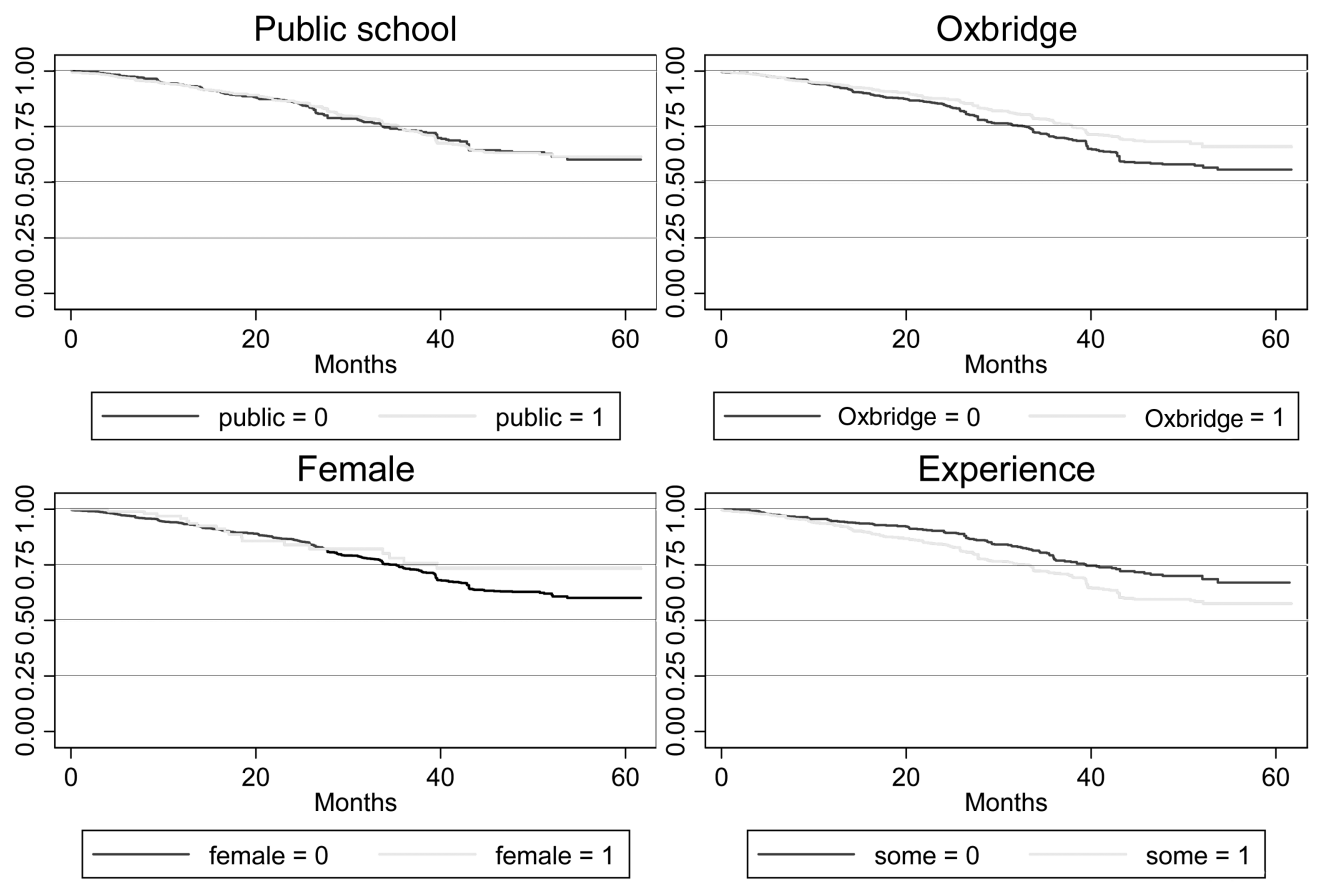

Fig. 2. Ministerial survivor function and individual characteristics 
ministerial characteristics acquired before entering a political career have some effect upon length of ministerial tenure.

In Figure 3, we look at some of the political effects. We look first for partisan differences in the survivor function, but such effects are not evident in these graphs. We also look for the impact of majority size. Serving in a government with a high majority, defined as having more than 55 per cent of the seats, does not affect the probability of surviving in any distinguishable way. We do, however, observe differences in the effect of the government term. The third graph appears to suggest that ministers serving in a prime minister's second term have lower survival probabilities. Surprisingly, the final graph in Figure 3 indicates that this effect might be driven by experienced ministers serving consecutive governments under the same prime minister. For a minister with no such previous experience, there is no difference in the survival probability when serving under a prime minister in her first or second term. These graphs appear to indicate that experience has a negative and robust effect on a minister's propensity to survive. We explore this issue in more detail below. ${ }^{31}$
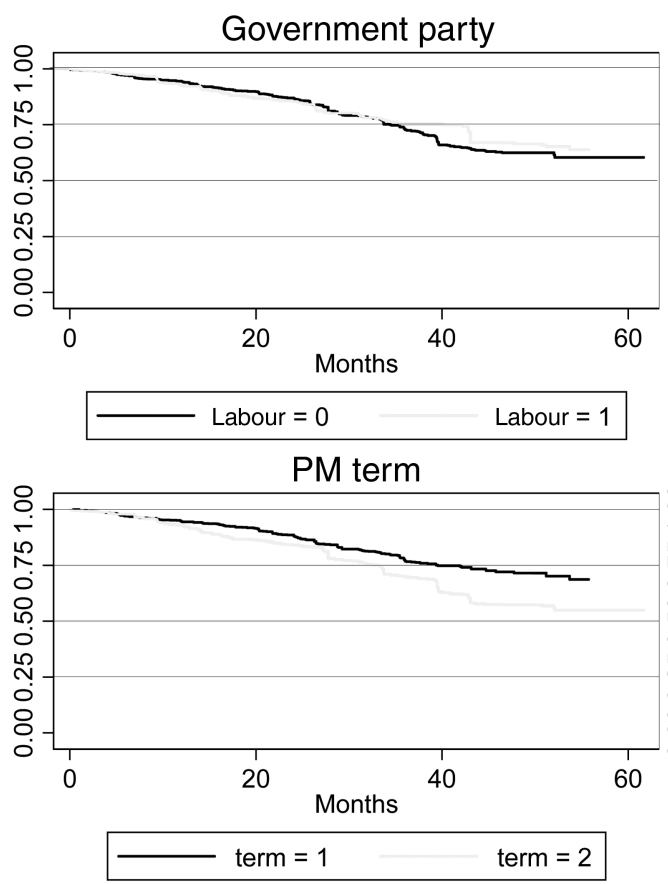

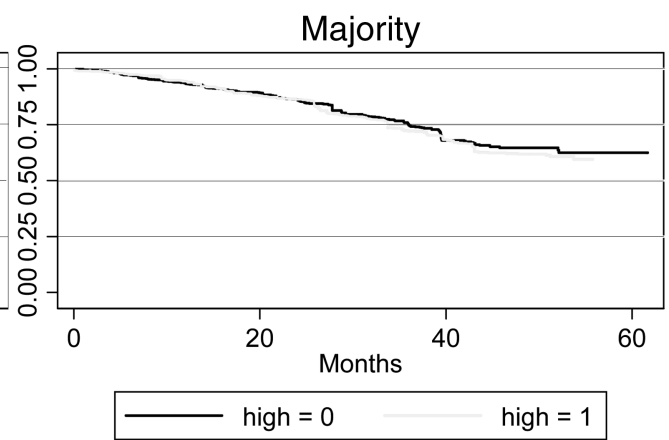

PM term: non-experienced ministers

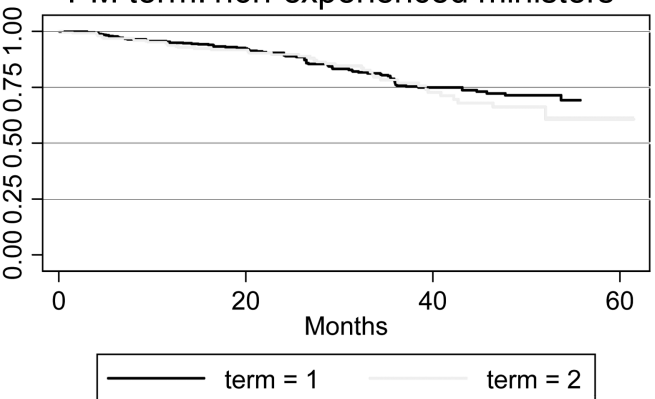

Fig. 3. Ministerial survivor function and government characteristics

THE DETERMINANTS OF MINISTERIAL HAZARD RATES

In the previous section, we have presented some interesting contrasts in the survival probabilities of ministers who either differ in their personal characteristics or in the

31 A logrank test confirms that the difference in the survivor functions of ministers serving in the first and second term of a prime minister is statistically significant. 
TABLE 4 The Determinants of Ministerial Durations: Hazard Ratios from Cox Models

\begin{tabular}{|c|c|c|c|c|}
\hline Variables & (1) & (2) & (3) & (4) \\
\hline \multirow[t]{2}{*}{ Public school } & $1.248 * *$ & 1.156 & 1.113 & 1.115 \\
\hline & $(0.137)$ & $(0.143)$ & $(0.139)$ & $(0.139)$ \\
\hline \multirow[t]{2}{*}{ Oxbridge } & $0.767 * *$ & $0.768 * *$ & $0.772 * *$ & $0.771 * *$ \\
\hline & $(0.080)$ & $(0.080)$ & $(0.081)$ & $(0.081)$ \\
\hline \multirow[t]{2}{*}{ Age } & $1.039 * * *$ & $1.041 * * *$ & $1.040 * * *$ & $1.040 * * *$ \\
\hline & $(0.006)$ & $(0.006)$ & $(0.006)$ & $(0.006)$ \\
\hline \multirow[t]{2}{*}{ Female } & $0.645 *$ & $0.602 * *$ & $0.628 *$ & $0.626 *$ \\
\hline & $(0.158)$ & $(0.148)$ & $(0.155)$ & $(0.155)$ \\
\hline \multirow[t]{2}{*}{ Some experience } & $1.584 * * *$ & $1.381 * * *$ & $1.442 * * *$ & $1.550 * * *$ \\
\hline & (0.174) & $(0.160)$ & $(0.176)$ & (0.197) \\
\hline \multirow[t]{2}{*}{ Unelected peer } & 0.971 & 0.964 & 0.949 & 0.949 \\
\hline & (0.113) & (0.113) & (0.111) & (0.111) \\
\hline \multirow[t]{2}{*}{ Ministers of cabinet rank } & $1.270 *$ & 1.240 & $1.256 *$ & $1.262 *$ \\
\hline & $(0.170)$ & $(0.166)$ & $(0.168)$ & $(0.169)$ \\
\hline \multirow[t]{2}{*}{ Junior ministers } & $1.724 * * *$ & $1.633 * * *$ & $1.653 * * *$ & $1.677 * * *$ \\
\hline & $(0.251)$ & $(0.239)$ & $(0.243)$ & $(0.247)$ \\
\hline \multirow{4}{*}{$\begin{array}{l}\text { Whips and members of } \\
\text { HM household } \\
\text { Majority }\end{array}$} & $2.585 * * *$ & $2.388 * * *$ & $2.558 * * *$ & $2.608 * * *$ \\
\hline & $(0.432)$ & $(0.402)$ & $(0.433)$ & $(0.444)$ \\
\hline & & 0.986 & 0.978 & \\
\hline & & $(0.012)$ & $(0.017)$ & \\
\hline \multirow[t]{2}{*}{ Labour } & & 0.869 & & \\
\hline & & $(0.105)$ & & \\
\hline \multirow[t]{2}{*}{ Second term } & & $1.458 * * *$ & $1.455^{* * *}$ & \\
\hline & & $(0.154)$ & (0.199) & \\
\hline \multirow[t]{2}{*}{ Third term } & & $1.545 * *$ & $2.156^{* * *}$ & \\
\hline & & $(0.279)$ & $(0.462)$ & \\
\hline Prime minister fixed effects & No & No & Yes & No \\
\hline $\begin{array}{l}\text { Primer minister } \times \text { Term } \\
\text { fixed effects }\end{array}$ & No & No & No & Yes \\
\hline Observations & 3,638 & 3,638 & 3,638 & 3,638 \\
\hline
\end{tabular}

Notes: Standard errors in parentheses. *Significant at $10 \% * *$ Significant at $5 \% * * *$ Significant at $1 \%$ See Table 1 for the definition of variables.

characteristics of the governments in which they serve. In this section, we try to disentangle the contribution of each of these factors upon a minister's hazard rate using a multivariate regression analysis.

In Tables 4 and 5, we present the impact of individual attributes on ministerial hazard rates. In column 1 of Table 4 , we condition only on individual attributes. We find that public school educated ministers have a hazard rate some 25 per cent higher than those ministers without a public school background. The hazard rate is lower for those who have been to Oxbridge ( 22 per cent). ${ }^{32}$ The educational credentials of a minister, as represented by attending a public school or Oxbridge, may capture some inherent characteristics of the minister such as acquired skills, latent ability or access to social networks. These

\footnotetext{
32 We have also included dummy variables for highest level of education attained which proved to be statistically insignificant.
} 
characteristics could be correlated with better on-the-job performance but this, in turn, may increase the value of a post-ministerial career. A priori, these factors may then contribute to either a decrease or increase in the minister's hazard rate. Our results, however, suggest that, on balance, an Oxbridge background leads to a decrease in a minister's hazard.

We have shown the existence of seniority effects as measured by age and its relationship to ministerial rank. We find that conditioning upon rank, age has a positive effect on ministerial hazard. An additional year increases the hazard rate of a minister by 4 percentage points. ${ }^{33}$ Here the explanation would seem to be that the older the minister when facing a problem, the more likely he is to feel he has reached the highest rung on the ladder and so be more willing to leave office to take a look at those outside options. And, of course, ministers may feel they have reached retirement age for a political career (though perhaps still young enough to make money outside of politics) and leave even when under no pressure to resign or move on. We also find that, although the number of female ministers in our sample is small, female ministers have lower hazard rates than males. This may be a reflection of the well-known finding that women generally are more risk averse than men. Women are thus less likely to engage in activity which may put their ministerial career at risk and, in that sense, individual hazards may be lower. Our results do not allow us to do more than speculate upon these reasons, however.

In terms of attributes attained during the minister's political career, we focus attention on previous experience of being in government. ${ }^{34}$ Much of the literature on ministerial turnover highlights experience as an indicator of ministerial ability and this might lead one to expect that experienced ministers have a greater capacity for survival. It has long been noted that the average level of experience amongst British ministers is lower than that in other countries. ${ }^{35}$ The reasons given usually point to the constraints faced by prime ministers who head multi-party cabinets. The coalitional politics of multi-party government means that factions must be kept happy and prime ministers have less control over who to select and de-select for their cabinets. The British prime minister must also select to keep factions in her party happy and may be forced to choose powerful colleagues for major positions and to choose some of their allies for junior positions in their departments. But the British prime minister still has much greater control over the selection and de-selection process, and she can certainly seize upon difficulties a minister has faced over time to usher them discreetly to the door.

We find that ministers who come to government with some ministerial experience have a hazard rate some 58 percentage points higher than those without previous experience.

33 We included a squared term in age which was not statistically significant.

34 We coded for experience in two ways. First, an experience variable measuring the years of ministerial experience in previous governments at the start of a spell. Secondly, a variable (some experience) coded 0 on first appointment and 1 for subsequent appointments in any later government term. The 'experience' variable (plus a squared term on 'experience') was insignificant when the 'some experience' variable was included. Thus, we have left only the categorical variable and when we refer to experienced ministers we mean those who have served a spell in a previous government. Newly appointed ministers are those appointed in the current term of government.

35 Mattei Dogan and Peter Campbell, 'Le personnel ministriel en France et en Grande-Bretagne', Revue Française de Science Politique (1957), 313-45; Philip Maynard Williams, Crisis and Compromise: Politics in the Fourth French Republic (Hamden, Conn.: Archone Books, 1964), p. 206; Herman, 'Comparative Perspectives'; John D. Huber and Cecilia Martinez-Gallardo, 'Cabinet Instability and the Accumulation of Experience: The French Fourth and Fifth Republics in Comparative Perspective', British Journal of Political Science, 34 (2004), 27-48. 
This finding, whilst consistent with evidence that British ministers on average are less experienced than ministers in other countries, is somewhat counter-intuitive. One would perhaps expect that experienced ministers have greater durability, especially if experience is correlated with ability. One reason why experienced ministers have shorter duration is that whilst at some point the marginal gains from remaining in office diminish, the corresponding risks do not. A minister who has served a long and valuable career, and who has his eye on a lucrative position upon leaving a political life, may be less willing to stick around when the going gets tough. At some point a concern for preserving an established reputation that may be useful outside of politics may take precedence over the desire for further political service. Or perhaps they simply get tired of the game. This finding may suggest that rather than British ministers being suboptimally inexperienced the British cabinet is closer to optimal experience than that seen in other countries. The pressures in Britain are more on the 'objective' features that reveal the abilities of ministers to run departments and deal with parliament, the media and the public than the factional coalitional politics that allows incompetents to stay in power.

Commentators have often bemoaned the fact of lower experience amongst British ministers in comparison to other countries, though Huber and Martinez-Gallardo make the crucial point that experience is not everything, and certainly we would not find an unchanging cabinet desirable. Nobody has yet modelled the optimal level of cabinet experience. ${ }^{36}$ Dewan and Dowding have demonstrated that getting rid of ministers is a way of weeding out bad ones - at least ones who detrimentally affect government popularity. ${ }^{37}$ But other factors may be at work.

In this model the hazard rate is decreasing with the rank of the minister. Government whips have a hazard rate some 159 percentage points higher than that of cabinet ministers; junior ministers have a hazard rate some 72 points higher; and ministers of cabinet rank a hazard rate some 30 points higher than their colleagues in cabinet. Whips are something of a special case. To resign as a whip does not necessarily affect one's future advancement, and whilst a time as a successful whip can enhance one's future career, being a successful whip is not thought to be an important indicator of ministerial quality. Higher rank should, one expect, correlate with latent factors such as quality picked up in the promotion process. So, whilst the fact that British prime ministers reshuffle more often and more easily than the premier of coalition governments the result of that shuffling ought to lead to the most able ministers remaining in the game. According to this view, the prime minister uses her power of patronage to reward the most able of her ministers, and the ability of the minister should be reflected in terms of longer tenure. Of course, promotion may also indicate other aspects of the relationship between the prime minister and minister, such as friendship or loyalty, but again the expected effect of these latent factors should be to increase the durability of the minister.

A mitigating factor, however, is that higher ranking ministers also face greater levels of scrutiny in parliament and the press. The actions of full cabinet ministers are subject to more scrutiny than lower ranking ministers, though junior ministers and ministers of cabinet rank are often associated with particular policies where failure may lead to close scrutiny. Where there is major departmental failure lower-ranked ministers will sometimes resign along with the full cabinet minister (as happened over Crichel Down, for example).

${ }^{36}$ Huber and Martinez-Gallardo, 'Cabinet Instability', pp. 46-7.

37 Dewan and Dowding, 'The Corrective Effect'. 
Cabinet ranked ministers may also face greater scrutiny of their personal lives though the press now seem to think that junior ministers are fair game for intense media scrutiny too. On balance, our results show that ministers appointed to jobs with a higher rank are more durable.

The last individual attribute we include is a dummy variable for members of the government who are unelected peers. Being in the House of Lords might have various effects. On the one hand, peers do not face re-election pressures, and thus they might have greater durability. A reinforcing effect is that lords face less media attention and may receive less hostile scrutiny - though again the House of Lords is often thought to have more careful debate. On the other hand, governments might find it difficult to identify competent peers to represent them in the Lords. On balance, we find that unelected peers are as durable as any other ministers in our sample.

One might suspect that all these results are due to the fact that ministers' characteristics are correlated with systematic features of the governments in which these ministers served. For example, we have seen in the previous section that Conservative ministers are more likely to have been to public school and Oxbridge. To disentangle these effects, in columns $2-4$, we condition on different sets of government characteristics. We start in column 2 with a set of obvious candidates such as which party is in government, the size of the party

TAB LE 5 The Determinants of Ministerial Durations for Selected Sub-samples: Hazard Ratios From Cox Models

\begin{tabular}{lcccc}
\hline \hline Variables & $(1)$ & $(2)$ & $(3)$ & $(4)$ \\
\hline Public school & 1.045 & 1.267 & 1.304 & 1.007 \\
Oxbridge & $(0.224)$ & $(0.215)$ & $(0.282)$ & $(0.156)$ \\
& $0.715^{*}$ & $0.753^{*}$ & 0.784 & $0.760 * *$ \\
Age & $(0.125)$ & $(0.110)$ & $(0.178)$ & $(0.090)$ \\
& $1.050^{* * *}$ & $1.036^{* * *}$ & $1.047 * *$ & $1.036^{* * *}$ \\
Female & $(0.010)$ & $(0.008)$ & $(0.011)$ & $(0.007)$ \\
& 0.935 & $0.514^{*}$ & 0.751 & $0.514 * *$ \\
Some experience & $(0.396)$ & $(0.178)$ & $(0.296)$ & $(0.168)$ \\
& 1.351 & $1.593 * *$ & $1.503 *$ & $1.570 * * *$ \\
Unelected peer & $(0.268)$ & $(0.294)$ & $(0.368)$ & $(0.235)$ \\
& 1.018 & 0.810 & 0.828 & 0.995 \\
Ministers of Cabinet rank & $(0.190)$ & $(0.136) *$ & $(0.192)$ & $(0.136)$ \\
& 1.093 & $1.540^{* *}$ & 1.487 & 1.192 \\
Junior ministers & $(0.238)$ & $(0.296)$ & $(0.360)$ & $(0.193)$ \\
& 1.411 & $1.988^{* * *}$ & 1.341 & $1.860^{* * *}$ \\
Whips and members of & $(0.354)$ & $(0.408)$ & $(0.374)$ & $(0.326)$ \\
$\quad$ HM household & $3.470 * * *$ & $2.598 * * *$ & $2.753 * * *$ & $2.630^{* * *}$ \\
Prime minister fixed effects & $(0.924)$ & $(0.637)$ & $(0.819)$ & $(0.557)$ \\
Primer minister $\times$ Term & Yes & Yes & No & No \\
fixed effects & No & No & Yes & Yes \\
Observations & 1,719 & 1,616 & 1,244 & 2,394 \\
\hline \hline
\end{tabular}

Notes: Standard errors in parentheses. *Significant at $10 \% * *$ Significant at $5 \% * * *$ Significant at $1 \%$. Column (1) has only ministers serving on the first term of a PM. Column (2) has only ministers serving on the second term of a PM. Column (3) has ministers serving only in Labour governments. Column (4) has minsters serving only in Conservative governments. See Table 1 for definiton of variables. 
majority and the term of the prime minister. ${ }^{38}$ In column 3 we condition upon prime minister fixed effects as well as government term and size of the party majority. The estimates from our most restrictive specification, including a dummy variable for each government, are presented in column 4. Surprisingly, the effects we found in column 1 are robust to these different specifications.

The political effects we have estimated could work in two ways: (i) they could shift up or down the baseline constant $\lambda_{0}$; (ii) they could affect the magnitude of the coefficients of the ministerial characteristics. For example, we have shown in Figure 3 that experience and term may interact with regard to the survival probability of the minister. In Table 5 we break down our sample according to government characteristics to study these effects. In column 1 we restrict the sample to ministers serving under a prime minister in her first term, in column 2 to those serving under a prime minister in her second term, in column 3 to ministers serving in Labour administrations and finally, in column 4, to ministers serving in Conservative administrations. All in all, our assessment is that the estimates of the impact of individual characteristics are of a similar magnitude to those presented in the previous table. However, in these model specifications these effects are less precisely estimated.

\section{CONCLUSION}

Using a unique dataset of all ministerial movements in Britain 1945-97 we have examined ministerial duration with a set of variables that capture both the individual characteristics of each minister as well as the political features of the government in which the minister was a member. Although differences in ministerial duration will reflect not only the problems each individual minister faces, as well as the specific historical events shaping each administration and the particular style of each prime minister, we have found that key systematic indicators of duration do exist.

Background variables such as education and gender affect a minister's capacity to survive with female ministers and those with an Oxbridge background having lower hazard rates. Attributes of a minister relating to political performance also have an effect. Higher ranking ministers have greater durability. We also find that experience increases ministerial hazard rates. These effects are robust to the inclusion of a large set of variables pertaining to the political characteristics of the government in which the minister serves.

Perhaps worth additional comment is the robustness of the effect of experienced ministers. The fact that experienced ministers have lower durations may provide some insight into the low levels of experience of ministers in government in Britain, as highlighted by previous studies of cabinet turnover. Many commentators and politicians have bemoaned the relatively low levels of experience and quality of ministers in British government. Whilst objectively assessing such claims is difficult. The ministerial job market is unlike most others which show increased durability with experience until a worker retires at some (usually fixed) age. That is not the case with ministers, and perhaps this is simply because it is a stage in a career rather than a career itself. Choosing the point to leave, given one's prospects in the ministerial job market, as opposed to one's prospects outside, is a fine point of judgement. If one's ministerial career appears to have reached

\footnotetext{
${ }^{38}$ We find no statistically significant partisan or majority effects. Ministers who are serving in the second term of a prime minister have 46 percentage points higher hazard rates relative to those serving in the first term, whereas those in a third term have a hazard rate 55 points higher.
} 
its zenith, then taking one's experience elsewhere may begin to look attractive. ${ }^{39}$ More junior ministers return to the back benches to serve their time out on committees and in the House, less constrained by loyalty to their party. More senior ministers tend not to remain on the back benches in the Commons for very long after they leave office (though of course there are many notable exceptions) but rather pursue careers outside of politics often with the sinecure of the back benches in the Lords. Either way, our findings suggest that there are diminishing marginal returns in a ministerial career in the structured context of single-party rule where the route to the top is more clearly ordained than in the less predictable rough-and-tumble of coalitional politics. It is its very predictability that may lead to less experienced ministers in the British one-party government system than are found in coalitional states. However, rather than suggesting that this is a problem for the British system of government, it may well be an indication that without the internecine political intrigues that keep possibly incompetent ministers in their jobs, the duration of senior ministers in Britain approaches optimality. We might ask, what other indications of optimality could we ask for? ${ }^{40}$

With the exception of Alt's 1975 study previous commentaries upon ministerial tenure have focused almost exclusively on the role of the prime minister in directing the cabinet. This is largely due to the fact that, whilst power is concentrated in the hands of a modern British prime minister, each prime minister has used that power in different ways. One would suspect that the personal characteristics of the prime minister and differences in the government will be a key determinant of ministerial tenure. Our results are important since they indicate the existence of systematic features of ministerial tenure related to ministerial characteristics which are independent of unique aspects of the government itself.

As well as offering a specific contribution to understanding the mechanics of British government our analysis contributes to the broader literature on ministerial careers and on key aspects of government duration. The literature examining legislative careers has not looked systematically at ministerial durability. ${ }^{41}$ The duration literature examining the forces and stresses of government break-up or cabinet instability has concentrated upon multi-party coalitions (though some comparative studies include countries with singleparty majorities). Whilst there is a growing literature on government durability, relatively little has been written about the durability of ministers themselves and, as noted by Huber and Martinez-Gallardo in their study of ministerial tenure in the French Fourth Republic, high rates of government turnover need not imply high rates of ministerial turnover. ${ }^{42}$ Strong single-party government also faces stresses which can be examined through ministerial turnover. There is an increasing interest in the systematic analysis of such ministerial turnover, ${ }^{43}$ and we hope the results presented here will help further understanding of this process.

${ }^{39}$ Chief executives may have similar hazards. Someone might work their way up through the management team of a company, but once at the top have a high hazard rating for that company, choosing to move to another such post sooner rather than later, perhaps whilst their company is doing well rather than when it fails.

40 We might note the finding from Table 2 that although Attlee's 1945 administration was the least experienced, most commentators see it as an efficient and enterprising government; and though Major's first administration was the most experienced (and his second highly experienced), they were seen as tired and inefficient.

${ }^{41}$ For example H. Best and M. Cotta, eds, Parliamentary Representatives in Europe 1848-2000: Legislative Recruitment and Careers in Eleven European Countries (Oxford: Oxford University Press, 2000).

42 Huber and Martinez-Gallardo, 'Cabinet Instability and the Accumulation of Experience'.

43 Dewan and Dowding, 'The Corrective Effect'; Dowding and Kang, 'Ministerial Resignations 1945-97'; Patrick Dumont, Leon De Winter and Regis Dandoy, 'Demissions gouvernmentales et performances electorales des majorities sortantes (1946-1999)', Courrier hebdomadaire du CRISP, No. 1722 (2001). 